\title{
Polyphony in Corporate and Organizational Communications: Exploring the Roots and Characteristics of a New Paradigm
}

Original scientific paper__DOI 10.22522/cmr20180232_ received on 24 August 2018 UDK: $316.77: 334.72-021 . \overline{38}$

$\ldots \ldots \ldots$

\section{Lena Schneider}

Lautenbach Sass, Germany. Email: schneider@lautenbachsass.de (corresponding author)

\section{Ansgar Zerfass, PhD}

Leipzig University, Germany; BI Norwegian Business School, Oslo. Email: zerfass@uni-leipzig.de

\section{Abstract}

This conceptual article examines the idea of polyphonic communication, which gained popularity as a new approach to integrate various voices and communicators in organizational settings. It argues that the metaphor of the organization speaking with many voices has not yet been clearly defined beyond metaphorical language, and the implications of polyphonic approaches for communication management have been rarely discussed - although empirical evidence shows that practitioners support this novel view. A review of the current use of polyphony in communications reveals key suppositions brought forward by authors like Christensen, Cornelissen, Falkheimer, Schultz, Zerfass and others. It also shows that a concise definition and operationalization is still missing. Thus, a broad literature analysis has been conducted to trace the root of polyphony across disciplines such as music, literature, psychology, politics and sociology. This lays the ground for a new, integrative definition of polyphony. Polyphony is understood as the integration of a multiplicity of internal and external voices into the communication activities managed by agents (i.e., communication departments or professionals) on behalf of a corporation or other organizations. Two approaches to managing polyphonic communication are identified and discussed in detail: deliberative-emergent and radical-emergent polyphony. This unveils the need for new and agile ways of communication management.

Keywords: corporate communication, organizational communication, consistency, ambiguity, polyphony 


\section{Introduction}

Corporations and their communication function have changed dramatically during the last decades. Many scholars argue that globalization, fragmentation of audiences, and the rise of social media have initiated a shift of power from top management to employees and from the organization to its stakeholders (e.g., Argenti, 2011, p.61; Duhé, 2017). Even scholars who have previously adhered to a functional understanding of corporate communications confirm that "strategic communication (...) earlier (...) characterized by a single source diffusing information to many has now been displaced by communication where many communicate with many" (Falkheimer, Heide, 2015, p. 343). Not only professional communicators but all stakeholders are creators of strategic messages. Empirical studies show a shift from paid, earned, and owned media (advertising, media relations, corporate publishing) to shared media (participating in social media discourses) in corporate communications practice (Macnamara et al., 2016). In this plurality of voices, the voice of the organization is only one among many (Holtz, 2002, p. 31). This has far-reaching consequences for the practice of communication management. As Murphy (2015, p. 124) described, "in a complex, tightly linked opinion environment, strategic communication can be purposeful and mindful, but it cannot control".

Concerning the study of communication management, these changes require a fundamental rethinking of organizational and corporate communications. Lars Thøger Christensen and colleagues (Christensen, Cornelissen, 2011, pp. 383-414; Christensen, Morsing, Cheney, 2008, pp. 196-212) argued that the idea of a comprehensive control of all communication activities needs to be revised. They proposed a paradigmatic change from centrally controlled to decentralized and multivocal organizational communication activities. This questions the traditional idea of integrating all communication activities and speaking with "one voice" (Cornelissen, 2012; Schultz, Schultz, 2003; Schultz, Tannenbaum, Lauterborn, 1994). It also asks for rethinking the role of professional communicators themselves. Christensen and his coauthors challenged prevalent presuppositions of control, consistency, and continuity by advocating implicit, ambiguous, and in part contradictory communication activities and a balance between centralized and decentralized articulation. They viewed the organization as a body with multiple voices and used the metaphor of "polyphony", borrowed from music, to state that it is the plurality of voices that creates a unique and distinctive organizational identity. 
This approach reflects the increasing interest for analyses of inconsistency in organizational communication research (e.g., Edwards, Fredriksson, 2017; Fredriksson, Pallas, 2017) and has been widely recognized and cited within the ongoing debate on further directions in strategic communication (e.g., Winkler, 2014, p. 181; Zerfass, Viertmann, 2016, p. 50; Zerfass et al., 2018). It also pervades practical discourses, where the multiplicity of voices is seen as a major challenge for communication professionals (e.g., Gallagher, 2012; Schultz, Morsing, 2014). Nevertheless, the concept of polyphony has not yet been clearly defined beyond metaphorical language. This makes it hard to capture its essence. In fact, this is rather risky, as any academic metaphor "can also be blinding and block our ability to gain an overall view" (Morgan, 1997, p. 347). Moreover, the concept has mostly been discussed from a rather broad and normative perspective. What is missing is an examination of polyphony in the context of corporations - who are key actors of professional communication in today's world - as well as a reflection on its implications for the management of communication. While the idea of getting away from one-voice messaging and giving freedom to many voices seems appealing at first glance, any questions about the possibility to manage multivoiced communication activities remain unanswered. It is also quite obvious that there are abundant academic studies on polyphony in other disciplines, which have not been recognized by organizational communication scholars so far.

This provides the starting point for this conceptual research. The aim of the article is to free the term "polyphony" from its metaphorical connotation and to examine it more holistically by integrating different aspects of the interdisciplinary discourse in one fundamental definition for organizational communication theory. Transferring this definition more specifically into the context of communication management then helps to reflect on a managerial perspective on polyphonic communication.

\section{Polyphony: An Interdisciplinary Search for Traces}

The term "polyphony" has its origin in the ancient Greek notion of poluphōnia (from polu"many" and phōne "sound") and refers to a great number of voices (Oxford Dictionaries, 2017). It is being applied within a wide variety of disciplines. The aim of the following analysis is to systematize these different understandings in order to formulate an abstract definition of polyphony that is applicable to an array of disciplines, including communications. 


\subsection{Polyphony in Music}

Polyphony is a musical concept. It is associated with music consisting of two or more distinct melodic lines and found especially in Western music (Encyclopaedia Britannica, 2014). In comparison to homophony, where one voice dominates the others, all voices have equal weight in polyphonic music. "Every participating voice of a musical piece is set as something independent by the composer and this independence is at the same moment part of a common polyphonic whole" (Schnaus, 2012). Thus, a central characteristic of polyphony is the independence of single voices. Furthermore, in comparison to heterophony, which describes the extemporaneous interplay of different voices, polyphonic music is always intentionally composed. Here the term polyphony is often associated with the notion of counterpoint. Counterpoint is the compositional technique involved in the handling of these independent melodic lines (Encyclopaedia Britannica, 2014).

\subsection{Polyphony in Literature and Linguistics}

The concept of polyphony is also discussed from a narrative as well as a linguistic perspective. The first is referred to as "literary polyphony", while the second is named "linguistic polyphony".

Literary polyphony originates with the Russian literary critic Michael M. Bakhtin. He described polyphony as a basic principle of the novel, which manifests itself especially in the work of the Russian author Fjodor M. Dostoevsky. According to Bakhtin (1984), the central characteristic of Dostoevsky's work is "a plurality of independent and unmerged voices and consciousnesses, a genuine polyphony of fully valid voices" (p. 6). In the so-called polyphonic novel, a dialogue emanates between the voices and worldviews of the different literary characters. In this interplay, the author does not play a passive role but rather joins the dialogue of the characters (p. 285).

While literary polyphony is examined on the level of narratives, linguistic polyphony is investigated within verbal expressions. There is a wealth of academic research on this form of polyphony (Nølke, Fløttum, Norén, 2004, p. 13). Dendale (2006) differentiated three schools, each with discrete models and terms. The first one developed around the French linguist Ducrot (1984), who referred to polyphony within his general theory of diction. He stated that the unity of the speaker splits into three different speaker subjects: the speaker 
who expresses the statement ("subject parlant"), comparable to the author of a text; the originator of the speech act who is responsible for the expression ("locutor"); and the voices that are staged by the speaker ("enonciatuer"), comparable to the narrator in literature. For Ducrot, polyphony arises when these different categories of voices overlap within a single expression. Following this, Nølke and colleagues (2004) developed the so-called théorie scandinave de la polyphonie linguistique (ScaPoLine). This conception also describes the existence of different verbal traces in one utterance while distinguishing further initiators of the utterance, their different points of views, and their relationships to each other. The third approach to linguistic polyphony is associated with the French linguist Bres (2001). His conception differs from previous ones by understanding polyphony not only as the relation between different points of view within one utterance but also between one utterance and one that has been expressed before.

To sum up, the main characteristic of polyphony in literature and linguistics lies in the specific role that the author as writer of the novel or speaker of the utterance plays. He or she is the initiator of polyphony and stages the voices and their dialogic interplay. In contrast to the conductor of a work of polyphonic music, the author not only stimulates the plurality of voices to perform together but also becomes a part of the plurality. The author's point of view becomes one among the others.

\subsection{Polyphony in Politics}

Polyphony in the field of politics is described as a typical trait of political discourse, as it allows for contradictions and ambiguity (Fløttum, 2010, p. 992; Gadinger, Jarzebski, Yildiz, 2014, p. 13). This marks an interesting field of application for the aforementioned concepts of literary and linguistic polyphony. For example, discourse analyses refer to polyphony to identify hidden intensions and implicit and unclear messages in political discourses (e.g., Maeße, 2010; Weber, 2013). Gadinger et al. (2014) applied Bakhtin's concept by outlining a first draft of a narrative theory in political science. Therein they replaced the notion of pluralism

with the term polyphony, considering that polyphony marks a stronger understanding of multiplicity than that traditionally used in political theory. Following these authors, polyphony has become an important characteristic of political narratives. The multiplicity of voices in political narratives and especially the blur and ambiguity of these voices makes the latent 
meanings of politics apparent. Thus, a central characteristic of polyphony in a political sense is that it allows for contradictions and ambiguity.

\subsection{Polyphony in Theater and Film}

The term "soloistic polyphony" refers to a specific form of staging that is characteristic for postmodern theater (Schrödl, 2012). In this field, a central characteristic of polyphony is stressed that has not yet been discussed, namely that polyphony has to be considered in two dimensions: production and perception. An actor may consciously stage the plurality of voices (production of polyphony), but it is the audience that determines whether the staging is effective or not (perception of polyphony). This means that an important role is played not only by the author, as the producer of polyphony, but also by the audience, which has to be open to perceiving the plurality. The existence of these two dimensions calls for a conception of polyphony as a process that is repeatedly created anew. This dimension of perception is also mentioned as a cinematic phenomenon. Although polyphony in film studies is seen as a comparatively unexplored innovation (Bruns, 2008, p. 189), investigations have shown that the term is understood as a coexistence of different interpretations that provide the audience with a plurality of possible constructions (Hartmann, Bruns, 2014).

\subsection{Polyphony in Psychology and Philosophy}

The idea of polyphony is also discussed in the fields of psychology and philosophy. The dialogical self theory in psychology transfers Bakhtin's thoughts about the polyphonic novel to the human identity. Here a person's self is seen in analogy to the different characters in the polyphonic novel as a plurality of relatively autonomous “I positions” (Hermans, Kempen, van Loon, 1992, p. 28). According to the Dutch psychologist Hermans (2001), a central implication of this understanding of identity is a far-reaching decentralization of the self. This can be experienced in situations in which different voices apparently clash within one's self, for example the voice of rationality and the voice of emotion. Within dialogical self theory, the spatial character of polyphony is emphasized, meaning that plurality always has to be considered in an imaginary space (Raggatt, 2012, p. 236). Furthermore, a central characteristic of polyphony in psychology lies in the fact that the different characters are not held together by a unifying will, but remain separate. Hermans (2001) states that "In this conception the 
existence of unity in the self, as closely related to continuity, does not contradict the existence of multiplicity, as closely related to discontinuity” (p. 248). The question addressed here about how the combination of unity and multiplicity in the self is possible has been discussed in the field of psychology and philosophy since the early 20th century. The German psychologist William Stern (1917) offered an interesting answer. Although he did not name it polyphony, his conception of the human being as "unitas multiplex" captured the idea of polyphony. He described the unitas multiplex as an individual that despite the multiplicity of its parts forms a particular and autonomous unity. This unity is constituted as a system of different layers, on every higher layer of which a unification and alignment of the different parts takes place. The development of the "I" at the highest layer is only possible through purposefulness (p. 39). It needs a certain goal to unify the different layers of the self. Renner and Laux (1994) pointed out that the different goals of the self vary in time and scale. There are goals that are temporally limited until they are reached, yet others may last for a lifetime. In summary, the debate on polyphony in psychology and philosophy shows that polyphony has to be considered in a spatial as well as a temporal dimension.

\subsection{Polyphony in Organizational Sociology and Communication Management}

There has been an abundance of academic examinations of polyphony in the fields of organizational sociology and organizational communication. Nevertheless, in the organizational context the phenomenon has not yet been consistently outlined. Andersen (2001) even claimed that polyphony has never reached beyond a metaphorical status. In contrast to the notions of polyphony in literature and linguistics, organizational theory has only developed very rare perceptions of where and in what forms polyphony exists (p. 17).

In organizational sociology, academic debate to date on polyphony has been characterized by two different research streams (Belova, King, Sliwa, 2008). The first stream has discussed polyphony as a narrative strategy of representing a plurality of voices in different text forms. For example, Barry and Elmes (1997) viewed the organizational strategy from a narrative perspective as one of many organizational stories. They addressed management to give up its monological control over the strategy narrative and instead utilize the different organizational stories for the strategy process. Others have investigated the manifestation of a plurality of 
voices in research papers. Here, while some have followed Bakhtin's notion of considering the voice of the researcher to be one out of many (e.g., Boje, Luhmann, Baack, 1999; Steyaert, Hjorth, 2002), for others the researcher has kept his or her dominant role (e.g., Czarniawska, 1999; Rhodes, 2000).

The second stream has expanded the metaphor of polyphony to the whole organization and understood the plurality of voices as one of its constitutive characteristics (e.g., Gergen, Whitney, 1996; Hazen, 1993). In this context the notion of polyphony introduces a new understanding of the organization. The organization is viewed as a discursive space, and organizational practices are seen as multicentral, nonlinear, and intersubjective activities (Belova et al., 2008, p. 494). The so-called polyphonic organization is not monolithic but pluralistic (Humphreys, Brown, 2002, p. 422). It is constituted by a multiplicity of narratives and discourses (Clegg et al., 2006, p. 19; Kornberger, Clegg, Carter, 2006, p. 14). The academic debate about the polyphonic organization unifies the assumption that polyphony in the organizational context is always present, even if it is drowned out by the dominant voices (Barry, Elmes, 1997; Carter et al., 2003; Cock, 1998). Most researchers have followed Hazen (1993) in assuming organizational change to occur as a natural consequence of the resistance of the marginalized voices against the dominant voice (e.g., Boje et al., 1999; Carter et al., 2003). Others like Sullivan and McCathy (2008) have referred more strongly to Bakhtin by integrating the specific role of the author to a larger extent. In their opinion the polyphonic organization, apart from an open dialogue, needs a management mind-set of critical reflection and a continuous balance of the truths of different stakeholders. Managing the polyphonic organization for Andersen (2001) means steering different organizational discourses and voices around stable anchoring points and in the absence of a given hierarchy. Forms of literary and linguistic polyphony can also be found in the field of organizational communication, more precisely in the analysis of management talk. Here the notion of inconsistency being an inevitable but also functional aspect of management communication prevails in the discussion (Fredriksson, Pallas, 2017). Hatch and Ehrlich (2002), for example, analyzed polyphony within management expressions by referring to the linguistic model of the ScaPoLine (e.g., Nølke et al., 2004), while Aggerholm and Thomsen (2015) based their analysis on Bakhtin's conception of the polyphonic novel. The latter authors stated that the voice of managers is inevitably polyphonic, because it always contains interests and concerns of different stakeholders. 
Within organizational communication and communication management research, Christensen and Cornelissen (2011, p. 402) argued that "The very concept of polyphony, and its study in episodes of communication, has been a hallmark of organizational communication research". In this context the idea of polyphony is tightly linked to the aforementioned concept of Christensen and colleagues. Their starting point was a critical discussion of the mostly unchallenged objective of organizations to speak with one voice. The authors considered polyphony to be an alternative to control-based approaches of integrated communication. For them, polyphony "presupposed the combination of diversity and unity within a coherent entity" (Christensen et al., 2008, p. 195). They advocated a complete realignment of organizational communication. Instead of communication being focused on explicitness, they preferred implicit messages that give room for agreement and a sense of community. Instead of fostering clarity, organizations should embrace ambiguity that allows for a plurality of opinions and interpretations. Additionally, consistency in their opinion is not something communicators should aim at. Discrepancies between different organizational messages but also between messages and successive actions of organizations are necessary to address different stakeholders simultaneously, and to adjust to different stakeholder needs. Last but not least, they criticized established practices of a central orchestration of messages. Instead, from their point of view, a decentralized articulation is needed not only from communication professionals but from all members of the organization. Christensen and colleagues further elaborated this concept in a wide range of research papers. For example, Christensen, Morsing, and Thyssen (2015) discussed the benefit of polyphony for the communication of organizational values. An applied field and example would be corporate social responsibility, in which discrepancies between communication about social activities and their manifestation in actions are necessary to raise higher standards of sustainability (Christensen, Morsing, Thyssen, 2013). According to this position, polyphony is also important in the context of organizational identity. Cheney, Christensen, Zorn and Ganesh (2004) argued for an abstract or ambiguous definition of the organization to help minimize contradictions between messages to different audiences.

While polyphony is here clearly linked to practices of communication management, it is depicted as a normative ideal. An explicit discussion of the plurality of voices within corporate communications and how these can be managed has not been put forward by Christensen and colleagues. Other researchers, however, have added to this understanding. 
Trittin and Schoeneborn (2017, p. 305) argued that polyphony is not only constituted by different internal voices, but it also develops around social discourses with stakeholders. Zerfass and Viertmann (2016) added another perspective by discussing polyphony in the interorganizational context. They interpreted it as a manifestation of any individual's and organization's freedom of expression. Form their point of view, polyphony plays a role for the organization and stakeholders alike. However, whether stakeholders perceive and accept polyphonic communication depends on their expectations toward the corporation (p. 55).

The conceptualization of polyphony by Christensen, Schoeneborn, Zerfass and others is consistent with many of the aforementioned characteristics of polyphony in other disciplines. The overarching and consistent idea is the equality of voices. Polyphony argues against any hierarchical structure of voices. Thus, organizational polyphony includes not only marginalized voices in organizations (e.g., Boje, 1995; Carter et al., 2003) but also voices from the organizational field and environment (e.g., Trittin, Schoeneborn, 2017; Zerfass, Viertmann, 2016).

\section{The Unifying Characteristics of Polyphony}

The reviewed interdisciplinary debate shows that polyphony is being discussed on different levels:

On a micro level, polyphony is inherent in single expressions. A speaker creates the plurality of voices by integrating different points of view into his or her utterance. This form of linguistic polyphony can be found in studies of theatrical representations (e.g., Schrödl, 2012), political discourses (e.g., Gadinger et al., 2014), and in the field of strategic communication (e.g., Aggerholm, Thomsen, 2015).

On a meso and macro level, polyphony is created by aggregating different voices. In contrast to the micro level, these voices might be expressed by different speakers. The predominant part of the previous analyses can be found on these two levels.

The synthesis of the analyzed understandings shows that polyphony always evolves around different parts, e.g., different characters, identities, or perspectives, and within a whole, e.g., a novel, an expression or a self (see Table 1). 
Table 1. Overview of interdisciplinary conceptualizations of polyphony

\begin{tabular}{|c|c|c|c|}
\hline Discipline & Conceptualization & Part (Plurality) & Whole (Unity) \\
\hline Music & Composition technique & Musical lines & Music piece \\
\hline Literature & Narrative principle & $\begin{array}{l}\text { Characters, } \\
\text { perspectives, } \\
\text { languages, styles }\end{array}$ & Narrative, novel \\
\hline Linguistics & Form of expression & $\begin{array}{l}\text { Opinions, points of } \\
\text { view }\end{array}$ & Verbal expression \\
\hline Politics & $\begin{array}{l}\text { Principle of discourse } \\
\text { and rhetoric, } \\
\text { understanding of } \\
\text { plurality }\end{array}$ & Messages, opinions & $\begin{array}{l}\text { Political narratives, } \\
\text { society }\end{array}$ \\
\hline Theater & Technique of staging & $\begin{array}{l}\text { Cultural patterns, } \\
\text { codes of voices }\end{array}$ & Theater performance \\
\hline Film & Principle of direction & $\begin{array}{l}\text { Narrative streams, } \\
\text { interpretations of a } \\
\text { film }\end{array}$ & Film \\
\hline $\begin{array}{l}\text { Psychology/ } \\
\text { Philosophy }\end{array}$ & Identity concept & $\begin{array}{l}\text { Partial identities, } \\
\text { internalized voices }\end{array}$ & Personality, self \\
\hline $\begin{array}{l}\text { Organizational } \\
\text { sociology }\end{array}$ & $\begin{array}{l}\text { Narrative principle, } \\
\text { understanding of the } \\
\text { organization }\end{array}$ & $\begin{array}{l}\text { Research perspectives, } \\
\text { organizational } \\
\text { narratives, voices } \\
\text { of organizational } \\
\text { members }\end{array}$ & $\begin{array}{l}\text { Research paper, } \\
\text { organization as a } \\
\text { whole }\end{array}$ \\
\hline $\begin{array}{l}\text { Organizational } \\
\text { communication }\end{array}$ & $\begin{array}{l}\text { Understanding of } \\
\text { communication }\end{array}$ & $\begin{array}{l}\text { Points of view, voices } \\
\text { of organizational } \\
\text { members, partial } \\
\text { identities of the } \\
\text { organization }\end{array}$ & $\begin{array}{l}\text { Messages, identity, } \\
\text { culture, image of the } \\
\text { organization }\end{array}$ \\
\hline
\end{tabular}

Thus, a first assumption based on the interdisciplinary analysis is:

\section{Polyphony is plurality and unity at once}

The plurality of voices does not lead to disorder but integrates different aspects into a unified whole. As Letiche (2010) described it, "Polyphony requires plurality and singularity: that is, polyphony demands multiple voices which remain distinct but nonetheless form the unity of an event" (p. 262). An interesting question here concerns the relationship between plurality and unity. As Gadinger et al. (2014, p. 20) stated, polyphony has to be understood 
not only as a multiplicity that moves toward unity, but also as its opposite. Following this, the multiplicity of voices can be considered as a starting as well as an ending point. As a starting point, polyphony arises as unity out of plurality; as an ending point, polyphony develops as plurality out of unity. This is an important differentiation for the latter part of this article.

Regarding unity, a second assumption is:

\section{Polyphony is an emergent phenomenon}

According to Bakhtin (1984), the created unity is of a higher order. This notion resembles the concept of emergence. Emergence is a specific trait of complex systems that cannot be reduced to its single components (Goldstein, 1999, p. 57). Considering polyphony, this means that the multiplicity of voices is more than the sum of every voice on its own. Music is a good example: The different melodic lines together create something new, a unique sound that is more than the different voices taken together.

A third assumption based on the literature review is that each discipline emphasizes different characteristics of the parts and the whole:

\section{The parts and the whole have special characteristics}

For example, the discourse in the field of music emphasizes the independence of voices in the overall polyphonic sound (e.g., Schnaus, 2012). As also noted by organizational sociology and organizational communication, the voices are equally independent of hierarchy, status, or context (e.g., Christensen et al., 2008; Hazen, 1993; Trittin, Schoeneborn, 2017; Zerfass, Viertmann, 2016). The discussion of polyphony within politics, however, focuses mainly on the characteristic of ambiguity. Polyphony here is described as a unity of contradictions and vagueness (e.g. Gadinger et al., 2014).

Finally, the interdisciplinary analysis has shown that polyphony includes many aspects:

\section{Polyphony is multidimensional}

As stressed in the field of music, polyphony is not a spontaneous phenomenon but rather intentionally created. This draws attention to the important role of authors, also found in 
literary and linguistic polyphony. As producer of polyphony, the author places the different voices and intentionally creates a sense of unity (e.g., Bakhtin, 1984). Thus, he or she holds an important structuring function. The analysis of polyphony in theater and film has shown that besides the perspective of the producer of polyphony there is always the perspective of the audience (e.g., Hartmann, Bruns, 2014; Schrödl, 2012). Thus, polyphony has to be examined in the dimension of production as well as in the dimension of perception. Both communicators and recipients are important. Besides that, the disciplines of psychology and philosophy emphasize that polyphony has a spatial and temporal dimension (e.g., Hermans et al., 1992), meaning that the different parts correlate with each other in different times and spaces.

Based on these four assumptions, polyphony can be defined in a general way:

Polyphony describes a state that stands for plurality and unity at once. A multiplicity of different and equal parts constitutes an ambiguous whole, which cannot be reduced to its single parts. Polyphony arises within the process of purposeful placement of the different parts and the perception of the provoked unity. It develops in a spatial as well as a temporal dimension.

\section{Defining Polyphony in Organizational and Corporate Communications}

This abstract definition shall now be transferred into organizational contexts. Here the parts stand for single communicative actions. Following a constitutive understanding of communication (e.g., Taylor, 1993), these actions form the identity, image, or brand of the organization. In analogy to the conductor of an orchestra, the communication manager holds the role of the producer of polyphony. He or she has to make sure that the different parts form a unity. This task calls for a purposeful, strategic approach; communicators will usually align their activities with the overarching goals of the organization, formal business plans, corporate social responsibility strategies, or similar objectives. However, the dimension of perception or reception as an inherent part of any communication process impairs the communicator's area of influence. It remains unsettled whether the full polyphony of voices is being perceived by the addressees of communication. The emergence of polyphony in a 
spatial dimension includes a decentralized articulation of voices on different hierarchy levels and in different communication departments and units, and it also includes voices outside the organization. This implies an extended understanding of corporate communications. It no longer includes only deliberately planned and controlled communication processes but also all forms of emergent and uncontrolled communication (e.g., Winkler, Etter, 2018). This comprises communicative actions that are not related to the roles of professional communicators as well as communications outside the organization. The temporal dimension of polyphony allows for discrepancies and inconsistencies between different articulations as well as between articulations and subsequent actions. Based on these findings, polyphony in the organizational context can be defined as the following:

Polyphony in organizational and corporate communications describes the integration of a multiplicity of internal and external voices into communication processes that are performed on behalf of the organization.

The main challenge for corporate communications lies in the integration of these different voices (plurality) into perceptible values of communication (unity) as well as in the alignment to strategic goals of the organization. Based on the aforementioned systematization of polyphony on a micro, meso, and macro level, the integration of voices can take place on different levels.

\subsection{Polyphony as Equivocal Communication Mode}

Polyphony on a micro level describes an equivocal communication mode. This goes hand in hand with the linguistic polyphony discussed earlier. Polyphony evolves around a multiplicity of implicit or explicit expressed viewpoints in a single expression. In analogy to the differentiated directions in the development of polyphony, plurality can be a starting as well as an ending point. As an ending point, polyphony implies the integration of different viewpoints of the addressed stakeholders in one expression. These forms of multiple expressions have been analyzed already in communication and management studies. For example, Aggerholm and Thomsen (2015), in an investigation of management team meetings, noted that "Talk by individual managers seem particularly multi-voiced in the sense that they must take the voices and arguments of many different stakeholders into consideration, such as, for example, investors, board members, white-collar employees, and blue-collar employees" (p. 177). In contrast, an expression can also be consciously vague, explicitly refusing to take a position. 
Plurality here is viewed as the ending point. This second form of a polyphonic communication mode resembles the concept of strategic ambiguity introduced by Eisenberg (1984). It includes "those instances where individuals use ambiguity purposefully to accomplish their goals" (p. 230). This concept is based on the assumption that clarity in some situations foils the strategic purposes of the communication. According to Eisenberg (1984), ambiguous communication is a rational management practice especially in turbulent environments because it fosters the development of a unified diversity. This diversity allows the alignment of communication to multifold goals and gives organizations room to adjust their actions continuously to new circumstances. Moreover, the attribution of a plurality of interpretations to one goal allows for collective action despite different interests (Christensen, Morsing, Cheney, 2008; Leitch, Davenport, 2007).

\subsection{Polyphony as Multivoiced Communication Strategy}

On a meso and macro level, polyphony defines a multivoiced communication strategy. These strategies can be interpreted in two different ways. In a narrow understanding, communication strategies are polyphonic in terms of content. In a wider understanding, these strategies are polyphonic in terms of structure. The latter version implies not only different voices but also different speakers articulating these voices.

In the case of polyphonic strategies around content, the orchestra of voices consists only of professional communicators. The communication director conducts the voices, giving them room for unfolding individual tones. An example can be found in international communication, in which a global messaging strategy can be adjusted by local communicators to the needs of specific markets, publics, or media environments. In the case of structural polyphonic strategies, the orchestra consists not only of professional communicators but also of employees from different functions and even external stakeholders. The integration of these voices into corporate communications has far-reaching consequences for communication management. It demands a specific mind-set of openness and appreciation of multiple voices. In this article, this is understood as a form of polyphonic communication policy. This notion refers to the fact that polyphony in this understanding is a task for the whole organization, and not only for communication specialists. Such a polyphonic communication policy forms an analytical counterpart to traditional "one-voice policies". This kind of organization-wide polyphony will be elaborated further in the next sections. 


\section{Polyphonic Communication Policy: Two Conceptual Perspectives}

In this article, polyphony is being understood as an emergent mode of strategic communication (Zerfass, Viertmann, 2016). The recognition of emergent processes and the renunciation of linearity together constitute a significant perspective of recent research (Holtzhausen, Zerfass, 2015, p. 7). Following this understanding, management abandons the prerogative of intentions over strategy formulation and flattens the way for a collective strategic learning process (Mintzberg, Waters, 1985, p. 270). Emergent strategies develop peripherally in the organization and follow a ritualistic rather than a linear process (Mintzberg, 1978, p. 947; Mintzberg, 1991, p. 14). They arise in consequence of constant, decentralized interactions. In contrast to deliberative strategies that are realized as intended, emergent strategies are realized despite or in the absence of intentions. Mintzberg and Waters (1985, p. 257) stressed that in reality the existence of purely emergent as well as purely deliberate strategies is unrealistic. Rather, they expected to find tendencies in one of the two directions, and they thus conceptualized the forms as two poles of a continuum.

This can be applied to polyphonic communication strategies as well, implicating that different forms of emergence can be identified. Thus, polyphonic communication develops in an open, flexible strategy process in which the idea of full control over strategy formulation is abandoned (Zerfass, Viertmann, 2016). However, the extent of renunciation of control varies and takes different forms. Along this line, two approaches to managing polyphonic communications can be distinguished depending on the controllability and autonomy of voices: deliberativeemergent polyphony and radical-emergent polyphony. These two forms constitute two poles of a continuum (see Figure 1) and differ particularly in the way unity is created. While on the left extreme of the continuum unity arises out of planning approaches and managing plurality, unity on the right pole develops out of plurality itself.

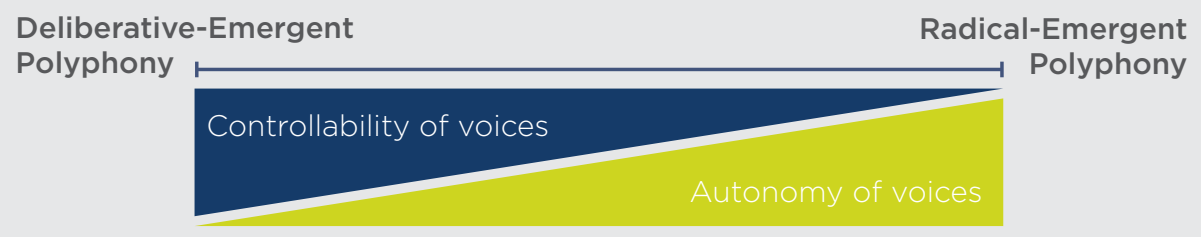

Figure 1. Conceptual perspectives of polyphonic communication strategies 


\subsection{Deliberative-Emergent Polyphony}

Deliberative-emergent approaches of polyphony posit that all stakeholders take a communicative role in the organization. Unity develops as communication management in charge of handling the overall function systematically chooses suitable speakers in the organization and outlines the barriers (e.g., compliance and governance rules) and the amount of freedom in which polyphony can unfold. This communicative freedom can be defined along van Riel's (1995) theory of common starting points (CSPs) and Motion and Leitch's (2002) thoughts on common end points (CEPs). Both CSPs and CEPs have been conceptualized as flexible orientation points and as an alternative to set values and communication goals. Van Riel (1995) described CSPs as "central values which function as the basis for undertaking any kinds of communication envisaged by an organization" (p. 19). Similarly, CEPs demonstrate a general direction without determining specific action patterns. Both CSPs and CEPs "do not imply a single tune but rather signify a common set of notes from which a variety of organizational tunes may be composed" (Leitch, Motion, 1999, p. 195). A prerequisite for this form of polyphony is that all voices are enabled to communicate. The deliberative-emergent concept of polyphony acknowledges the need to manage communications for an organization and thus to respect governance structures, i.e., in the form of communication departments and professionals overseeing the communication function. Because the formation of emergent strategies will be suppressed by hierarchical structures (Winkler, 2015, p. 43), some forms of heterarchical arrangements are necessary to complement traditional planning routines (Winter, 2009, p. 1). This creates peripheral room for maneuver for the plurality of voices to arise.

\subsection{Radical-Emergent Polyphony}

In contrast, a radical-emergent approach to polyphonic communication avoids centralized management and control. This form of communication policy is not compatible with hierarchical setups of the communication function. Instead it calls for a decentralized structure with small, semiautonomous groups developing organic forms of communication management. A separate communication department may be dispensable or reduced to some basic support and coaching roles, as in this model all stakeholders create communication. Following the idea of the "communicative organization" (Hamrefors, 2009, 2010) and based on the concept of microboundary spanning (Kim, Rhee, 2011), all voices cooperate in the 
dissemination of organizational messages, the inclusion of valuable organization-related information from internal and external constituencies, and the internal sharing of the acquired information. The concept of flexible integration (Christensen, Firat, Torp, 2008) helps to grasp the idea of how unity is created. Following Christensen and colleagues, a communicative integration needs a common repertoire of so-called common process rules (CPRs). They are not designed to regulate processes; rather, they can guide the actors in the process of discovering new ideas and solutions. Thus, CPRs enable the self-steering of voices by defining the rules of their situational interplay. According to the authors, flexible integration has to rely on cooperation between CSPs and CEPs on the one hand and CPRs on the other hand. This conceptualization is not only vague but also holds some discrepancies because it builds on two basically different integration modes (Winkler, 2014, p. 191). While CSPs and CEPs represent a self-referential integration aimed at reducing ambiguity, CPRs stand for promoting ambiguity. Following Winkler (2014), CSPs, CEPs, and CPRs have to be considered as indirectly proportional rather than complementarily arranged (p. 232). This forms the basis of the analytical differentiation between the specification of central values and aims in the deliberative-emergent concept of polyphonic communication and the open, processual rules within radical-emergent polyphony. In line with the understanding that empowerment implies competence as well as authority (Chiles, Zorn, 1995), voices within radical-emergent polyphony are not only enabled to communicate, but also empowered to independently implement communication. Table 2 shows a comparison of the two forms.

Table 2. Comparison of the two conceptual perspectives of polyphony

\begin{tabular}{|c|c|c|}
\hline Characteristic & $\begin{array}{l}\text { Deliberative-Emergent } \\
\text { Polyphony }\end{array}$ & Radical-Emergent Polyphony \\
\hline Management of communications & Centralized management & Decentralized self-management \\
\hline Autonomy of voices & Enablement & Empowerment \\
\hline Creation of unity & $\begin{array}{l}\text { Defining strategic guidelines } \\
\text { (CSPs + CEPs) }\end{array}$ & Securing common rules (CPRs) \\
\hline
\end{tabular}

It is important to stress that this is an analytical differentiation. Different forms of polyphonic communication strategies may evolve in practice, based on the respective corporate strategies and the situational conditions for corporate communications. 


\section{Implications and Recommendations for Research and Practice}

This article has examined polyphonic communication from a communication management perspective with the aim of sharpening the concept of polyphony in the organizational context. It thereby answers the call for "bridging corporate and organizational communication" addressed by Christensen and Cornelissen (2011) when introducing the idea of polyphony. Polyphony has been conceptualized from a multidisciplinary perspective. The article thus responds to the demand for overcoming the disciplinary isolation of communication management research. The definition and conceptualization of polyphony presented here provides the groundwork for further research, which might focus on several aspects:

Polyphony in organizational settings different from corporations. It can be assumed that a polyphonic approach to communication is easier to implement in nonprofit organizations, in which members are less strictly bound to a codified regulatory framework and operational goals.

Conceptualizing polyphonic communication policies. The two perspectives developed in this article may not be discrete options for communication practices but rather overall stages for developing the communication function in organizations. The professionalization of communication from a small start-up to an established corporation could be investigated referring to the two poles as a process model to elaborate on this understanding.

Investigating drawbacks of a multivoiced communication. Dulek and Campbell (2015) pointed out that strategic communication always has a dark side. The use of polyphonic communication modes embracing ambiguity might be misused for the deception of stakeholders and publics. Further research might focus on these aspects.

Empirical validation. A survey of communication managers and employees from other organizational departments could disclose whether polyphonic strategies have already been implemented in organizations, and to what extent and under which conditions.

There are also some implications of this article for the practice of corporate communications. Although the arguments are conceptual in nature, they provide some thought-provoking 
ideas for communication managers. The idea of polyphony sensitizes one to the need for new management concepts in corporate communications. The way communication is managed must inevitably be revised in a digital world. Communication practitioners have to give up control over communication by letting other actors outside traditional communication departments speak on behalf of the organization. The continuum of polyphonic communication policies developed in this article may outline strategic approaches that help to handle multiple voices in and around organizations.

\section{Reference List}

- Aggerholm, H. K., Thomsen, C. (2015). Strategic communication. The role of polyphony in management team meetings. In: D. R. Holtzhausen \& A. Zerfass (Eds.), The Routledge handbook of strategic communication (pp. 172-186). New York, NY: Routledge.

- Andersen, N. A. (2001). Polyphonic organisations (Working Paper). Copenhagen: Copenhagen Business School, Department of Management, Politics and Philosophy.

- Argenti, P. A. (2011). Digital strategies for powerful corporate communications. The European Financial Review, FebruaryMarch, 61-64.

- Bakhtin, M. (1984). Problems of Dostoevsky’s poetics. Minneapolis, MN: University of Minnesota Press.

- Barry, D., Elmes, M. (1997). Strategy retold: Toward a narrative view of strategic discourse. The Academy of Management Review, 22 (2), 429-452. https://doi.org/10.2307/259329

- Belova, O., King, I., Sliwa, M. (2008). Introduction: Polyphony and organization studies: Mikhail Bakhtin and beyond. Organization Studies, 29 (4), 493-500. https://doi.org/10.1177/0170840608088696

- Boje, D. M. (1995). Stories of storytelling organisation: A postmodern analysis of Disney as “Tamara-Land”. Academy of Management Journal, 38 (4), 997-1035. https://doi.org/10.2307/256618

- Boje, D. M., Luhmann, J. T., Baack, D. E. (1999). Hegemonic stories and encounters between storytelling organizations. Journal of Management Inquiry, 8 (4), 340-560. https://doi.org/10.1177/105649269984002

- Bres, J. (2001). “Dialogique”, “Dialogisme”, “Dialogisme (Marqueurs de -)”. In: C. Détrie, P. Siblot, B. Verine (Eds.), Termes et concepts pour l'analyse du discours. Une approche praxématique [Terms and concepts for discourse analysis] (pp. 86-89). Paris, France: Champion.

- Bruns, J. (2008). The polyphonic film. New Review of Film and Television Studies, 6 (2), 189-212. https://doi. org/10.1080/17400300802098313

- Carter, C., Clegg, S., Hogan, J., Kornberger, M. (2003). The polyphonic spree: The case of the Liverpool dockers. Industrial Relations Journal, 34 (4), 290-304. https://doi.org/10.1111/1468-2338.00276

- Cheney, G., Christensen, L. T., Zorn, T. E., Ganesh, S. (2004). Organizational communication in an age of globalization. Issues, reflections, practices. Prospect Heights, IL: Waveland Press.

- Chiles, A. M., Zorn, T. E. (1995). Empowerment in organizations: Employees' perceptions of the influences on empowerment. Journal of Applied Communication Research, 23, 1-25. https://doi.org/10.1080/00909889509365411

- Christensen, L. T., Cornelissen, J. (2011). Bridging corporate and organizational communication: Review, development and a look to the future. Management Communication Quarterly, 25 (3), 383-414. https://doi.org/10.1177/0893318910390194

- Christensen, L. T., Firat, A. F., Torp, S. (2008). The organisation of integrated communications: Toward flexible integration. European Journal of Marketing, 42 (3/4), 423-452. https://doi.org/10.1108/03090560810853002

- Christensen, L. T., Morsing, M., Cheney, G. (2008). Corporate communications: Convention, complexity and critique. London, UK: Sage.

- Christensen, L. T., Morsing, M., Thyssen, O. (2013). CSR as aspirational talk. Organization, 20 (3), 372-393. https://doi. org/10.1177/1350508413478310 
- Christensen, L. T., Morsing, M., Thyssen, O. (2015). The polyphony of values and the value of polyphony. Journal for Communication Studies, 8 (1), 9-25. https://doi.org/10.1177/0170840608088696

- Clegg, S. R., Kornberger, M., Carter, C., Rhodes, C. (2006). For management? Management Learning, 37 (1), 7-27. https:// doi.org/10.1177/1350507606060975

- Cock, C. de. (1998). Organisational change and discourse: Hegemony, resistance and reconstitution. Management, 1 (1), 1-22. https://doi.org/10.1177/2329488414560107

- Cornelissen, J. (2012). Corporate communication: A guide to theory and practice (3rd ed.). London, UK: Sage.

- Czarniawska, B. (1999). Writing management: Organization theory as a literary genre. Oxford, UK: Oxford University Press.

- Dendale, P. (2006). Three linguistic theories of polyphony/dialogism: An external point of view and comparison. In: N. Møller Andersen, H. Nølke, R. Therkelsen (Eds.), Sproglig polyfoni [Linguistic polyphony] (pp. 3-32). Roskilde, Denmark: Institut for Sprog og Kultur, Roskilde Universitetscenter.

- Ducrot, O. (1984). Le dire et le dit. Paris, France: Minuit.

- Duhé, S. C. (Ed.). (2017). New Media and Public Relations (3rd ed.). New York, NY: Peter Lang.

- Dulek, R. E., Campbell, K. S. (2015). On the dark side of strategic communication. International Journal of Business Communication, 52 (1), 122-142. https://doi.org/10.1177/2329488414560107

- Edwards, L., Fredriksson, M. (2017). Forum: Inconsistency and communication in organizations. Management Communication Quarterly, 31 (3), 467-472. https://doi.org/10.1177/0893318917699886

- Eisenberg, E. M. (1984). Ambiguity as strategy in organizational communication. Communication Monographs, 51, $227-242$. https://doi.org/10.1080/03637758409390197

- Encyclopaedia Britannica. (2014). Polyphony. Retrieved from https://www.britannica.com/art/polyphony-music. 10.12.2018.

- Falkheimer, J., Heide, M. (2015). Strategic communication in participatory culture: From one- and two-way communication to participatory communication through social media. In: D. R. Holtzhausen, A. Zerfass (Eds.), The Routledge handbook of strategic communication (pp. 337-349). New York, NY: Routledge.

- Fløttum, K. (2010). EU discourse: Polyphony and unclearness. Journal of Pragmatics, 42 (4), 990-999. https://doi.org/10.1016/j. pragma.2009.08.014

- Fredriksson, M., Pallas, J. (2017). Translated inconsistency: Management communication under the reign of institutional ambiguity. Management Communication Quarterly, 31 (3), 473-478. https://doi.org/10.1177/0893318917699887

- Gadinger, F., Jarzebski, S., Yildiz, T. (2014). Politische Narrative. Konturen einer politikwissenschaftlichen Erzähltheorie [Political narratives. Outlines of a political science orientied narrative theory]. In: F. Gadinger, S. Jarzebski, T. Yildiz (Eds.), Politische Narrative. Konzepte - Analysen - Forschungspraxis [Political narratives: Concepts - analyses - research practice] (pp. 3-38). Wiesbaden, Germany: Springer VS.

- Gallagher, D. (2012). Why “polyphony” may be the new black in communications. Retrieved from http://blog.ketchum.com/ why-polyphony-may-be-the-new-black-in-communications/. 10.12.2018.

- Gergen, K., Whitney, D. (1996). Technologies of representation in the global corporation: Power and polyphony. In: D. M. Boje, R. P. Gephart, T. J. Thatchenkery (Eds.), Postmodern management and organization theory (pp. 331-357). Thousand Oaks, CA: Sage.

- Goldstein, J. (1999). Emergence as a construct: History and issues. Emergence, 1 (1), 49-72. https://doi.org/10.1207/ s15327000em0101_4

- Hamrefors, S. (2009). The professional communicator's role in leadership: Final report in the research project "Business Effective Professional Communication". Stockholm, Sweden: The Swedish PR Association.

- Hamrefors, S. (2010). Communicative leadership. Journal of Communication Management, 14 (2), 141-152. https://doi. org/10.1108/13632541011034592

- Hartmann, B., Bruns, K. (2014). Lexikon der Filmbegriffe [Encyclopedia of film terms]: Polyphony. Retrieved from http:// filmlexikon.uni-kiel.de/index.php?action=lexikon \&tag=det \&id=8518. 10.12.2018.

- Hatch, M. J., Ehrlich, S. (2002). The dialogic organization. In: N. C. Roberts (Ed.), The transformative power of dialogue (pp. 107-131). Bingley, UK: Emerald Group Publishing Limited. 
- Hazen, M. A. (1993). Towards polyphonic organizaton. Journal of Organizational Change Management, 6 (5), 15-29. https:// doi.org/10.1108/09534819310072747

- Hermans, H. J. M. (2001). The dialogical self: Toward a theory of personal and cultural positioning. Culture \& Psychology, 7 (3), 243-281. https://doi.org/10.1177/1354067X0173001

- Hermans, H., Kempen, H., van Loon, R. (1992). The dialogical self: Beyond individualism and rationalism. American Psychologist, 47, 23-33. https://doi.org/10.1037/0003-066X.47.1.23

- Holtz, S. (2002). Public relations on the net. Winning strategies to inform and influence the media, the investment community, the government, the public, and more! (2nd ed.). New York, NY: AMACOM.

- Holtzhausen, D. R., Zerfass, A. (2015). Strategic communication: Opportunities and challenges of the research area. In: D. R. Holtzhausen, A. Zerfass (Eds.), The Routledge handbook of strategic communication (pp. 3-17). New York, NY: Routledge.

- Humphreys, M., Brown, A. D. (2002). Narratives of organizational identity and identification: A case study of hegemony and resistance. Organization Studies, 23 (3), 421-447. https://doi.org/10.1177/0170840602233005

- Kim, J.-N., Rhee, Y. (2011). Strategic thinking about employee communication behavior (ECB) in public relations: Testing the models of megaphoning and scouting effects in Korea. Journal of Public Relations Research, 23 (3), 243-268. https://doi. org/10.1080/1062726X.2011.582204

- Kornberger, M., Clegg, S. R., Carter, C. (2006). Rethinking the polyphonic organization: Managing as discursive practice. Scandinavian Journal of Management, 22, 3-30. https://doi.org/10.1016/j.scaman.2005.05.004

- Leitch, S., Davenport, S. (2007). Strategic ambiguity as a discourse practice: The role of keywords in the discourse on "sustainable" biotechnology. Discourse Studies, 9, 43-61. https://doi.org/10.1177/1461445607072106

- Leitch, S., Motion, J. (1999). Multiplicity in corporate identity strategy. Corporate Communications: An International Journal, 4 (4), 193-199. https://doi.org/10.1108/13563289910299319

- Letiche, H. (2010). Polyphony and its other. Organization Studies, 31 (3), 261-277. https://doi.org/10.1177/0170840609357386

- Macnamara, J., Lwin, M., Adi, A., Zerfass, A. (2016). "PESO” media strategy shifts to “SOEP”: Opportunities and ethical dilemmas. Public Relations Review, 42 (3), 377-385. https://doi.org/10.1016/j.pubrev.2016.03.001

- Maeße, J. (2010). Die vielen Stimmen des Bologna-Prozesses. Zur diskursiven Logik eines bildungspolitischen Programms. [The many voices of the Bologna process. About the discoursive logic of an education program]. Bielefeld, Germany: Transcript.

- Mintzberg, H. (1978). Patterns in strategy formation. Management Science, 24 (9), 934-948. https://doi.org/10.1287/mnsc.24.9.934

- Mintzberg, H. (1991). Five Ps for strategy. In: H. Mintzberg, J. B. Quinn (Eds.), The strategy process. Concepts, contexts, cases (2nd ed., pp. 12-19). Englewood Cliffs, NJ: Prentice-Hall.

- Mintzberg, H., Waters, J.A. (1985). Of strategies, deliberate and emergent. Strategic Management Journal, 6, 257-272. https:// doi.org/10.1002/smj.4250060306

- Morgan, G. (1997). Images of organizations. Thousand Oaks, CA: Sage.

- Motion, J., Leitch, S. (2002). The technologies of corporate identity. International Studies of Management \& Organization, 32 (3), 45-64.

- Murphy, P. (2015). Contextual distortion. Strategic communication versus the networked nature of nearly everything. In: D. R. Holtzhausen, A. Zerfass (Eds.), The Routledge handbook of strategic communication (pp. 113-126). New York, NY: Routledge.

- Nølke, H., Fløttum, K., Norén, C. (2004). ScaPoLine. La théorie scandinave de la polyphonie linguistique. [The Scandinavian theory of linguistic polyphony]. Paris, France: Kimé.

- Oxford Dictionaries. (2017). Polyphony. Retrieved from https://en.oxforddictionaries.com/definition/polyphony. 10.12.2018.

- Raggatt, P. (2012). Personal chronotopes in the dialogical self: A developmental case study. In: M.-C. Bertau, M. M. Gonçalves, P. Raggatt (Eds.), Dialogic formations: Investigations into the origins of the dialogical self (pp. 235-250). Charlotte, NC: Information Age Publishing.

- Renner, K.-H., Laux, L. (1994, September). William Sterns unitas multiplex und das Selbst in der Postmoderne [William Stern's unitas multiplex and the self in postmodernity]. Paper presented at the 39th congress of the German Society for Psychology, Hamburg, Germany.

- Rhodes, C. (2000). Reading and writing organizational lives. Organization, 7 (1), 7-29. https://doi.org/10.1177/135050840071002 
- Schnaus, P. (2012). Polyphonie: Die Anfänge der Mehrstimmigkeit [Polyphony: The beginning of multivoiceness]. Retrieved from http://universal_lexikon.deacademic.com/286723/Polyphonie\%3A_Die_Anf\%C3\%A4nge_der_Mehrstimmigkeit.10.12.2018.

- Schrödl, J. (2012). Stimm-Maskeraden. Zur Politik der Polyphonie [Voice masquerades. To the politics of polyphony]. In: K. Friedemann, M. Bachmann, J. Pfahl, D. Volz (Eds.), Theater und Subjektkonstitution: Theatrale Praktiken zwischen Affirmation und Subversion [Theater and constitution of the subject: Theatric practices between affirmation and subversion] (pp. 145-157). Bielefeld, Germany: Transcript.

- Schultz, F., Morsing, M. (2014). Embracing dissent: How have digital tools and new media helped communicators meet the challenges of globalisation? Communication Director, 1, 78-81.

- Schultz, D. E., Schultz, H. (2003). IMC. The next generation. Fixe steps for delivering value and measuring returns using marketing communication. New York, NY: McGraw-Hill.

- Schultz, D. E., Tannenbaum, S. I., Lauterborn, R. F. (1994). The new marketing paradigm: Integrated marketing communications. Chicago, IL: NTC Business Books.

- Stern, W. (1917). Die Psychologie und der Personalismus [The psychology and the personalism]. Zeitschrift für Psychologie, $78(1 / 2), 1-54$.

- Steyaert, C., Hjorth, D. (2002). 'Thou art a scholar, speak to it...' - on spaces of speech: A script. Human Relations, 55 (7), 767-797. https://doi.org/10.1177/0018726702055007540

- Sullivan, P., McCathy, J. (2008). Managing the polyphonic sounds of organizational truths. Organization Studies, 29 (4), 525-542. https://doi.org/10.1177/0170840608088702

- Taylor, J. R. (1993). Rethinking the theory of organizational communication: How to read an organization. Norwood, NJ: Ablex Publishing.

- Trittin, H., Schoeneborn, D. (2017). Diversity as polyphony: Reconceptualizing diversity management from a communicationcentered perspective. Journal of Business Ethics, 144 (2), 305-322. https://doi.org/10.1007/s10551-015-2825-8

- van Riel, C. (1995). Principles of corporate communication. London, UK, New York, NY: Prentice Hall.

- Weber, F. D. (2013). Soziale Stadt - Politique de la Ville - Politische Logiken. (Re-)Produktion kultureller Differenzierungen in quartiersbezogenen Stadtpolitiken in Deutschland und Frankreich: [Social city - urban policy - political logics]. Wiesbaden, Germany: Springer VS.

- Winkler, P. (2014). Eine PR der nächsten Gesellschaft: Ambivalenzen einer Disziplin im Wandel [PR of the next society. Ambivalences of a changing discipline]. Wiesbaden, Germany: Springer VS.

- Winkler, P. (2015). Wider die reine Netzwerkrhetorik - Plädoyer für eine netzwerksoziologisch informierte Online-PR [Against pure network theory - plea for a network sociologic informed online PR]. In: O. Hoffjann, T. Pleil (Eds.), Strategische Onlinekommunikation. Theoretische Konzepte und empirische Befunde [Strategic online communication. Theoretcical concepts and empirical findings] (pp. 31-53). Wiesbaden, Germany: Springer VS.

- Winkler, P., Etter, M. (2018). Strategic communication and emergence: A dual narrative framework. International Journal of Strategic Communication, 12 (4), 382-398. https://doi.org/10.1080/1553118X.2018.1452241)

- Winter, J. (2009). Zwischen Hierarchie und Heterarchie [Between hierarchy and heterarchy]. Berlin, Germany: LIT.

- Zerfass, A., Viertmann, C. (2016). Multiple voices in corporations and the challenge for strategic communication. In: M. Brown, K. Alm, S. Røyseng (Eds.), Kommunikasjon og ytringsfrihet i organisasjoner [Communication and freedom of expression in organizations] (pp. 44-63). Oslo, Norway: Cappelen Damm.

- Zerfass, A., Verčič, D., Nothhaft, H., Werder, K. P. (2018). Strategic Communication: Defining the Field and its Contribution to Research and Practice. International Journal of Strategic Communication, 12 (4), 487-505. https://doi.org/10.1080/15531 18X.2018.1493485 

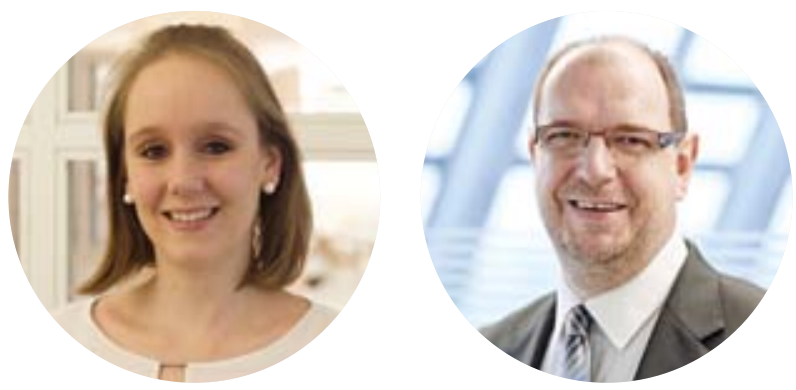

\section{Lena Schneider Ansgar Zerfass}

Lena Schneider is Consultant at Lautenbach Sass, a consultancy specialized in communication management in Frankfurt, Germany.
Ansgar Zerfass is Professor and Chair of Strategic Communication at Leipzig University, Germany, and Professor of Communication and Leadership at BI Norwegian Business School, Oslo. 